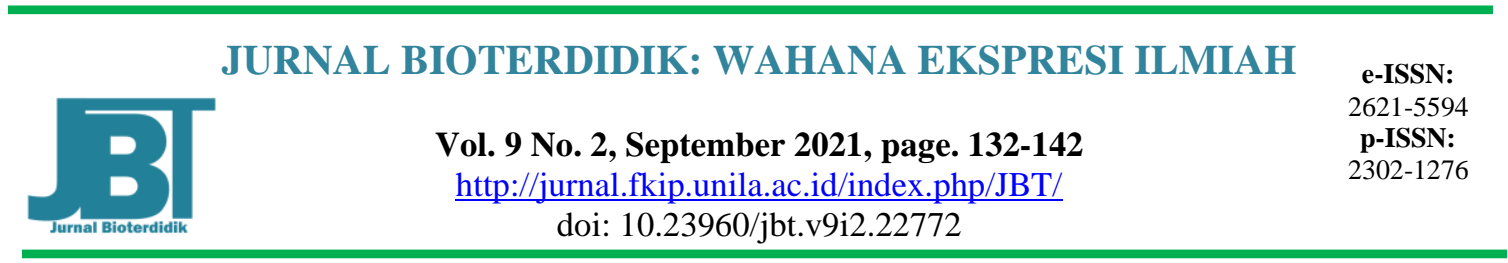

\title{
Pengaruh Model Pembelajaran Inkuiri Terimbing Berbasis Kearifan Lokal Terhadap Kemampuan Berpikir Kreatif Peserta Didik Pada Materi Bioteknologi
}

\author{
Berti Yolida*, Median Agus Priadi, Darlen Sikumbang, Nanda Denny \\ Program Studi Pendidikan Biologi, FKIP Universitas Lampung \\ Universitas Lampung, JL. Prof. Dr. Soemantri Bojonegoro No.1 Bandar Lampung \\ *email: berti.yolida@fkip.unila.ac.id HP: 082280249700
}

\begin{abstract}
The Influence of Guided Inquiry Learning Model Based on Local Wisdom on Students' Creative Thinking Ability in Biotechnology Materials. This study aims to determine the effect of local wisdom-based guided inquiry learning models on students' creative thinking skill. The design in this research used a pretest-posttest non-equivalent control grup. The sample of this research was students of class IX E dan IX $F$ which were sampled from the population in a cluster random sampling manner. Data in this research were quantitatif data obtained fromnthe average pretest, posttest, and $N$-gain values which were then statistically analyzed using the $t$ test at 5\% confidence level through the SPSS 17. The results showed that the creative thinking skill of experimental class students obtained good criteria with an average acquisition of 58.9 and it is known that the significance value at sig. (2-tailed) $<0.05$ which means that there is a significant influence on the experimental class. Thus, learning using guided inquiry models based on local wisdom influences students' creative thinking skill.
\end{abstract}

Keywords: creative thingking skill, bioteknology, guided inquiry learning, local wisdom

\begin{abstract}
Abstrak: Pengaruh Model Pembelajaran Inkuiri Terimbing Berbasis Kearifan Lokal Terhadap Kemampuan Berpikir Kreatif Peserta Didik Pada Materi Bioteknologi. Penelitian ini bertujuan untuk mengetahui pengaruh model pembelajaran inkuiri terbimbing berbasis kearifan lokal terhadap kemampuan berpikir kreatif peserta didik. Desain dalam penelitian ini menggunakan pretest-posttest non-equivalent control grup. Sampel penelitian adalah peserta didik kelas IX E dan IX F yang dicuplik dari populasi secara cluster random sampling. Data dalam penelitian ini berupa data kuantiatif yang diperoleh dari rata-rata nilai pretest, posttest dan $\mathrm{N}$-gain yang kemudian dianalisis secara statistik menggunakan uji t pada taraf kepercayaan 5\% melalui program SPSS 17. Hasil penelitian menunjukan bahwa kemampuan berpikir kreatif peserta didik kelas eksperimen diperoleh kriteria baik dengan perolehan rata-rata sebesar 58,9 dan diketahui bahwa nilai signifikansi pada sig. (2-tailed) $<0,05$ yang artinya terdapat pengaruh signifikan pada kelas eksperimen. Dengan demikian, pembelajaran menggunakan model inkuiri terbimbing berbasis kearifan lokal berpengaruh terhap kemampuan berpikir kreatif peserta didik.
\end{abstract}

Kata kunci: bioteknologi, kearifan lokal, model pembelajaran inkuiri terbimbing, kemampuan berpikir kreatif 


\section{PENDAHULUAN}

Pendidikan memberdayakan potensi manusia untuk mewariskan, mengembangkan serta membangun kebudayaan dan peradaban masa depan. Pendidikan memiliki peran untuk melestarikan nilai-nilai budaya yang positif, selain itu pendidikan berfungsi untuk menciptakan perubahan ke arah kehidupan yang lebih kreatif dan inovatif. Dengan terciptanya kehidupan yang kreatif dan inovatif akan memberi dampak positif bagi lingkungan karena dapat mendorong aktualisasi dan potensi diri yang dimiliki (Dharma, 2008: 52). Seiring dengan perkembangan abad 21 yang dikenal sebagai abad pengetahuan yang merupakan landasan utama untuk berbagai aspek kehidupan dan bertujuan untuk meningkatkan intelegensi dan kemampuan berpikir peserta didik dalam pembelajaran (Tilaar, 2010: 10). Melalui penyelenggaraan pendidikan berbasis masyarakat dan budaya lokal, pendidikan juga berperan dalam pengembangan kebudayaan daerah setempat. Undang-Undang Republik Indonesia tahun 2003 tentang Sistem Pendidikan Nasional pada Bab 1 Ketentuan Umum pasal 1 ayat 16 menyebutkan bahwa pendidikan berbasis masyarakat merupakan penyelenggaraan pendidikan berdasarkan kekhasan agama, sosial, budaya, aspirasi, dan potensi masyarakat sebagai perwujudan pendidikan dari, oleh dan untuk masyarakat.

Berdasarkan pedoman umum pembelajaran pada Permendikbud Nomor 81A Tahun 2013 mengenai pembelajaran Ilmu Pengetahuan Alam (IPA), proses pembelajaran IPA di sekolah harus memberikan kesempatan kepada siswa untuk mengembangkan potensi dalam bidang sikap, pengetahuan, maupun keterampilan (Permendikbud, 2013). Pembelajaran IPA merupakan pembelajaran yang melibatkan beberapa aspek antara lain proses berpikir kritis, pengamatan, dan kesadaran dalam mengamati gejala-gejala alam yang terjadi di sekitar lingkungan. Lingkungan adalah sumber belajar yang pertama dan utama. Konsep-konsep yang rumit dan abstrak dalam IPA akan lebih mudah dipahami apabila dalam pembelajarannya disertakan dengan contoh-contoh yang konkrit yaitu contoh yang wajar sesuai dengan situasi dan kondisi lingkungan yang dihadapi (Lestari, 2018: 40). Peraturan Pemerintah RI Nomor 19 Tahun 2005 Bab III Pasal 14 Ayat 1 menyatakan bahwa kurikulum SMP/MTs/SMPLB atau bentuk lain yang sederajat, dapat memasukkan pendidikan berbasis keunggulan lokal. Keunggulan lokal masyarakat daerah Lampung yang dikenal sangat kaya mulai dari kreasi seni berupa alat musik, tarian daerah, rumah adat, kebiasaan-kebiasaan masyarakat serta makanan seperti tempoyak, bekasem, tapai pisang, seghuit, terasi dan lain-lain menjadi keunggulan masyarakat lokal yang dapat diintegrasikan kedalam proses pembelajaran melalui metode, pendekatan atau model yang digunakan.

Pembelajaran berbasis kearifan lokal mengintergrasikan budaya sebagai bagian dari proses pembelajaran. Dalam pembelajaran IPA banyak sumber dan objek yang ada dalam lingkungn relevan untuk dijadikan contoh konkrit sebagai solusi konsep yang rumit dan abstrak dalam pembelajaran IPA. Sardjiyo dan Panen (2005: 15) mengemukakan bahwa proses pembelajaran IPA berbasis kearifan lokal tidak hanya mentransfer budaya serta perwujudan budaya tetapi menggunakan budaya untuk menjadikan siswa mampu menciptakan makna, menembus batas imajinasi, dan kreatif dalam mencapai pemahaman yang mendalam tentang mata pelajaran yang dipelajari. Melalui pemahaman yang mendalam itu peserta didik dapat berpikir secara kreatif dalam memecahkan masalahmasalah yang ada. Kemampuan berpikir kreatif dipandang penting karena akan membuat peserta didik memiliki banyak cara dalam menyelesaikan berbagai persoalan dengan berbagai persepsi dan konsep yang berbeda (Awang dan Ramly, 2008: 8). 
Pengembangan berpikir kreatif pada peserta didik ini sangat penting. Terdapat empat alasan pentingnya pengembangan berpikir kreatif, yaitu kemampuan kreatif orang dapat mewujudkan (mengaktualisasi) diri sendiri, kemampuan kreatif sebagai kemampuan untuk melihat bermacam-macam kemungkinan untuk menyelesaikan suatu masalah, bersibuk diri secara kreatif memberi kepuasan pada individu, dan kemampan kreatiflah yang membuat manusia mampu meningkatkan kualitas hidupnya (Munandar, 2009: 39). Namun faktanya, kemampuan berpikir kreatif individu Indonesia masih tergolong rendah. Hal ini dapat dilihat dari peringkat kreativitas Indonesia berdasarkan Global Creativity Index tahun 2015 dimana Indonesia menempati peringkat ke-115 dari 139 negara (Florida, 2015: 57).

Rendahnya kemampuan berpikir kreatif juga ditemukan pada peserta didik kelas IX SMP Negeri 3 Natar. Berdasarkan hasil wawancara, pendidik mengaku bahwa belum sepenuhnya mengembangkan kemampuan berpikir peserta didik. Pendidik belum melaksanakan pembelajaran yang menuntut peserta didik mengembangkan cara berpikirnya baik itu berpikir kritis, berpikir kreatif, ataupun berpikir tingkat tinggi. Hal ini dikarenakan minat peserta didik untuk berpikir dan belajar cenderung masih kurang. Peserta didik masih merasa kesulitan untuk memahami konsep-konsep yang abstrak dalam IPA. Untuk itu, pendidik sebenarnya dapat mengadopsi kearifan lokal masyarakat setempat untuk dijadikan sumber belajar agar dalam proses pembelajaran peserta didik dapat mengontruksi pengetahuan barunya dengan situasi lingkungan sekitar dan tidak menemukan lagi konsep-konsep yang abstrak seperti sebelumnya. Rendahnya minat peserta didik untuk berpikir dan belajar juga dapat disebabkan karena proses pembelajaran yang monoton. Pendidik mengaku bahwa belum pernah menerapkan model-model pembelajaran secara utuh pada saat proses pembelajaran dan belum pernah menjadikan kearifan lokal sebagai salah satu sumber belajar. Akibatnya hasil belajar kogntif peserta didik pun tidak maksimal. Hampir sekitar $65 \%$ peserta didik kelas IX SMP Negeri 3 Natar belum mencapai KKM pada materi bioteknologi.

Kemampuan berpikir kreatif dapat dikembangkan melalui proses pembelajaran di kelas dengan menerapkan beberapa model pembelajaran, salah satunya model pembelajaran inkuiri terbimbing. Model pembelajaran inkuiri terbimbing merupakan model pembelajaran yang berupaya menanamkan dasar-dasar berpikir ilmiah pada diri peserta didik, sehingga peserta didik mampu mengembangkan kreativitas dalam memahami konsep dan memecahkan masalah (Hendra, 2007: 26). Melalui inkuiri terbimbing, peserta didik belajar berorientasi pada bimbingan dan petunjuk dari pendidik hingga peserta didik dapat memahami konsep-konsep pembelajaran. Selama proses belajar, peserta didik akan memperoleh pedoman sesuai dengan yang diperlukan. Pada tahap awal, pendidik banyak memberikan bimbingan, kemudian pada tahap-tahap berikutnya, bimbingan tersebut dikurangi, sehingga peserta didik mampu melakukan proses inkuiri secara mandiri. Bimbingan yang diberikan dapat berupa pertanyaanpertanyaan dan diskusi multi arah yang dapat mengarahkan peserta didik agar dapat memahami konsep pelajaran yang disampaikan. Dengan begitu dapat mengembangkan kemampuan intelektual peserta didik dan kemampuan berpikir kreatif dalam seperti mengajukan pertanyaan dan menemukan (mencari) jawaban yang berawal dari keingintahuan mereka (Rustaman, 2005: 65).

Konsep-konsep pelajaran dalam IPA yang lebih mudah dipahami apabila dalam pembelajarannya disertakan dengan contoh-contoh yang konkrit sesuai dengan situasi dan kondisi lingkungan yang dihadapi juga akan memudahkan peserta didik dalam memahami konsep pelajaran yang disampaikan. Model pembelajaran inkuiri terbimbing 
dapat diintegrasikan dengan kearifan lokal masyarakat setempat agar peserta didik dapat mengontruksi pengetahuan yang telah mereka miliki dengan konsep baru yang ditemukan melalui proses inkuiri sehingga peserta didik dapat memahami konsep pembelajaran yang dimaksud melalui kearifan lokal daerah dimana ia tinggal serta memahami bahwa sesungguhnya terdapat hubungan yang berkaitan antara pengalaman belajar peserta didik melalui proses penemuan inkuiri dengan kebudayaan setempat. Model inkuiri terbimbing berbasis kearifan lokal menjadikan peserta didik lebih aktif, kritis, kreatif dan mengemukakan sebuah data dengan hasil percobaan yang telah dilakukan dengan bimbingan guru (Lestari, 2018: 18). Dengan demikian diharapkan melalui model inkuiri terbimbing berbasis kearifan lokal, peserta didik dapat kesempatan untuk mengembangkan dan mengasah kemampuan berpikir kreatif yang dimiliki peserta didik dalam pembelajaran khususnya mampu menyelesaikan soal yang ada dalam kehidupan sehari-hari. Hal ini sesuai dengan hasil penelitian yang telah dilakukan oleh Wijayanti dkk (2014: 26) yang menyebutkan bahwa terdapat perbedaan hasil belajar yang signifikan antara siswa yang belajar dengan menggunakan model pembelajaran inkuiri terbimbing dan model pembelajaran konvensional. Penelitian lain diungkapkan oleh Suardana (2013: 53) bahwa pembelajaran inkuiri terbimbing berbasis kearifan budaya lokal efektif dalam meningkatkan keterampilan berpikir kritis siswa. Selanjutnya, temuan lain oleh Azizahwati, dkk (2015: 73) menunjukkan bahwa pencapaian hasil belajar siswa setelah mengikuti proses pembelajaran dengan menggunakan perangkat pembelajaran berorientasi kearifan lokal mengalami peningkatan.

Berdasarkan uraian di atas maka dilakukan penelitian yang bertujuan untuk menganalisis pengaruh penggunaan model inkuiri terbimbing berbasis kearifan lokal terhadap berpikir kreatif peserta didik pada materi bioteknologi kelas IX SMP Negeri 3 Natar.

\section{METODE}

Penelitian ini dilaksanakan pada semester genap bulan Febuari 2020 di SMP Negeri 3 Natar. Populasi dalam penelitian ini adalah seluruh peserta didik kelas IX semester genap SMP Negeri 3 Natar dengan sampel penelitian kelas IX E sebagai kelas kontrol dan IX F sebagai kelas eksperimen yang dicuplik dengan teknik cluster random sampling. Penelitian ini merupakan eksperimental semu (quasi eksperimental) dengan desain pretest-posttest kelompok tak ekuivalen (Tabel 1).

\begin{tabular}{|c|c|c|c|}
\hline Kelompok & Pretest & $\begin{array}{c}\text { Variabel } \\
\text { bebas }\end{array}$ & Posttest \\
\hline$E$ & Y1 & $X$ & Y2 \\
\hline $\mathrm{C}$ & Y1 & - & Y2 \\
\hline
\end{tabular}

Kedua kelompok diberi tes berupa soal pilihan ganda beralasan yang sama sebanyak 20 soal di awal dan diakhir kegiatan pembelajaran (pretest-posttest). Data dalam penelitian ini berupa data kuantitatif yang diperoleh dari nilai pretest-posttest, dan NGain yang dianalisis secara statistik menggunakan uji $t$ dengan taraf kepercayaan $5 \%$ namun sebelumnya dilakukan uji prasyarat berupa uji normalitas dan kesamaan dua varians (homogentas) data. 


\section{HASIL PENELITIAN}

Pengolahan dan analisis data dalam penelitian ini dilakukan dengan menggunakan bantuan software analisis statistik yaitu SPSS 17.0 terhadap nilai pretest, posttest dan NGain.Perbandingan antara nilai pretest, posttest dan N-Gain dapat dilihat pada tabel berikut.

Tabel 2. Hasil tabulasi perbandingan nilai pretest, posttest, dan N-Gain

\begin{tabular}{ccccc}
\hline Kelas & $\begin{array}{c}\text { Rata-Rata } \\
\text { Pretest }\end{array}$ & $\begin{array}{c}\text { Rata-Rata } \\
\text { Posttest }\end{array}$ & $\begin{array}{c}\text { N-Gain } \\
(\%)\end{array}$ & $\begin{array}{c}\text { Interpretasi } \\
\text { N-Gain }\end{array}$ \\
\hline Eksperimen & 37,2 & 74,3 & 58,9 & Baik \\
\hline Kontrol & 34,9 & 58,6 & 35,6 & Kurang \\
\hline
\end{tabular}

Berdasarkan Tabel 2 di atas, dapat diketahui bahwa kemampuan berpikir kreatif peserta didik pada kelas eksperimen memiliki kriteria baik dengan rata-rata $\mathrm{N}$-Gain sebesar 58,9. Sedangkan pada kelas kontrol memiliki kriteria kurang dengan rata-rata $\mathrm{N}$-Gain sebesar 35,6. Distribusi N-Gain pretest-posttest pada masing masing kelas dapat dilihat pada gambar di bawah ini.

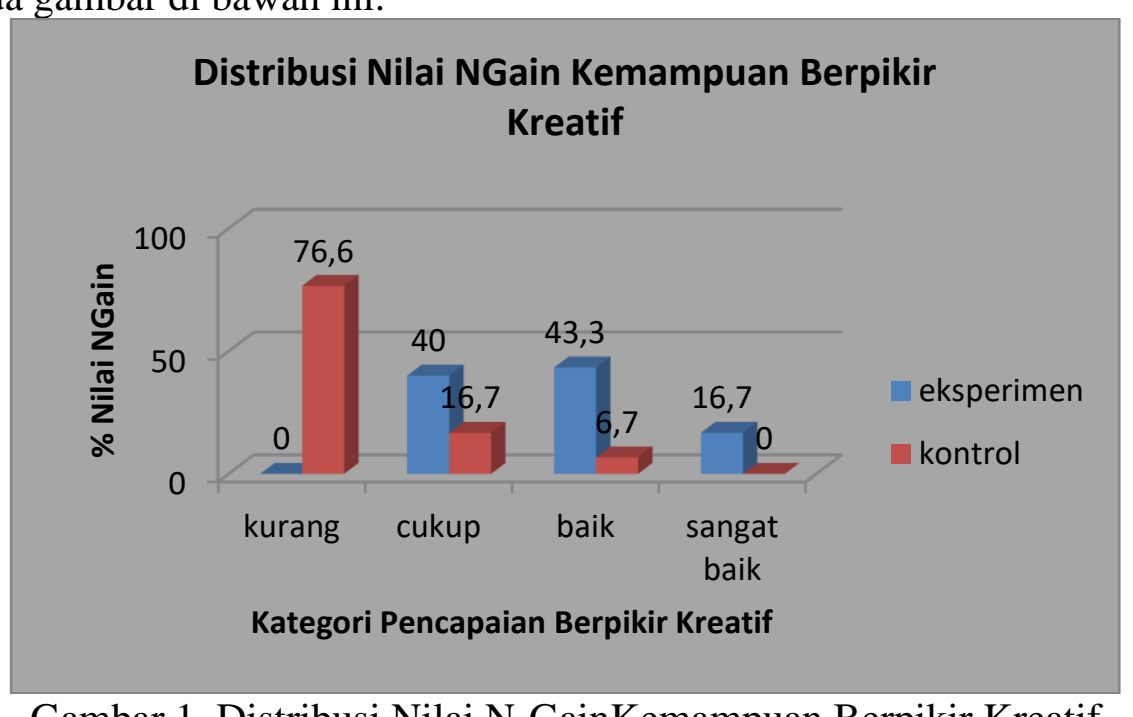

Gambar 1. Distribusi Nilai N-GainKemampuan Berpikir Kreatif

Berdasarkan Gambar 1 di atas, dapat diketahui bahwa sebaran N-Gain pretestposttest pada kelas eksperimen tertinggi pada kriteria baik dengan persentase $43,4 \%$ sedangkan pada kontrol tertinggi pada kriteria kurang dengan persentasi 76,6\%. Dengan demikian, hasil penelitian menunjukan bahwa kriteria N-Gain kelas eksperimen lebih baik daripada kelas kontrol, yang artinya distribusi N-Gain kemampuan berpikir kreatif pada kelas eksperimen lebih baik dari kelas kontrol. Untuk mengetahui data dari masing-masing aspek kemampuan berpikir kreatif, dapat dilihat pada Tabel 3 berikut.

Tabel 3. Hasil Analisis Rata-Rata Setiap Indikator Berpikir Kreatif pada Kelas Eksperimen dan Kelas Kontrol

\begin{tabular}{ccccccc}
\hline No. & Kelas & Indikator & $\begin{array}{c}\text { Rata-rata } \\
\text { pretest }\end{array}$ & Kriteria & $\begin{array}{c}\text { Rata-rata } \\
\text { posttest }\end{array}$ & Kriteria \\
\hline & & Fluency & 41 & Cukup & 77 & Sangat baik \\
\cline { 3 - 7 } & & Flexibility & 38 & Kurang & 76 & Sangat baik \\
\cline { 3 - 7 } 1 & Eksperimen & Originality & 37 & Kurang & 78 & Sangat baik \\
\hline
\end{tabular}




\begin{tabular}{|c|c|c|c|c|c|c|}
\hline & & Elaboration & 35 & Kurang & 70 & Baik \\
\hline & Rata-rata & $\left.{ }^{x}\right) \pm \mathrm{StDev}$ & $37,7 \pm 2,5$ & Kurang & $75,2 \pm 3,5$ & Baik \\
\hline \multirow{5}{*}{2} & \multirow{4}{*}{ Kontrol } & Fluency & 33 & Kurang & 58 & Baik \\
\hline & & Flexibility & 35 & Kurang & 58 & Baik \\
\hline & & Originality & 37 & Kurang & 64 & Baik \\
\hline & & Elaboration & 37 & Kurang & 55 & Cukup \\
\hline & Rata-rata & $\left.{ }^{c}\right) \pm \mathrm{StDev}$ & $35,5 \pm 1,9$ & Kurang & $58,7 \pm 3,7$ & Baik \\
\hline
\end{tabular}

Berdasarkan Tabel 3 di atas, diketahui bahwa kemampuan berpikir kreatif peserta didik perindikator pada kelas eksperimen memiliki nilai yang lebih besar dari kelas kontrol. Data kelas eksperimen didapatkan hasil rata-rata pretest pada indikator berpikir kreatif kelas eksperimen sebesar 37,7 dan hasil rata-rata posttest sebesar 75,2. sedangkan data kelas kontrol didapatkan hasil rata-rata pretest pada indikator berpikir kreatif kelas eksperimen sebesar 35,5 dan hasil rata-rata posttest sebesar 58,7.

Uji statistik dilakukan dengan bantuan SPSS 17.0 terhadap nilai N-Gain. Data yang diperoleh dianalisis melalui uji normalitas, uji homogenitas dan uji Independent Sample t-test. Hasil uji statistik dapat dilihat pada tabel berikut.

Tabel 4.Hasil Tabulasi Uji Statistik N-Gain Kemampuan Berpikir Kreatif

\begin{tabular}{ccccc}
\hline Nilai & Kelas & Uji Normalitas & Uji Homogenitas & $\begin{array}{c}\text { Uji Independet } \\
\text { Sample t-test }\end{array}$ \\
\hline NGain & & & & Sig. 0,26>0,05 \\
& $\mathrm{E}$ & Sig. $0,56>0,05$ & & $0,00<0,05$ \\
& $\mathrm{~K}$ & Sig. 0,86>0,05 & & \\
\hline
\end{tabular}

Berdasarkan Tabel 4, setelah data pretest, posttest dan N-Gain hasil belajar kognitif peserta didik dilakukan uji normalitas menggunakan uji Kolmogorov-Smirnov, diperoleh hasil bahwa sampel berasal dari populasi yang berdistribusi normal baik pada kelas eksperimen maupun kelas kontrol. Uji homogenitas menggunakan uji Levene Test terhadap data pretest, posttest dan N-Gain hasil belajar kognitif peserta didik diperoleh bahwa data yang diuji memiliki varians yang homogen. Setelah dilakukan uji normalitas dan homogenitas data, selanjutnya dilakukan uji Independent-Sample t-test untuk menguji signifikansi beda rata-rata dua kelas antara peserta didik kelas eksperimen dan kelas kontrol, diperoleh hasil sig. 0,00< 0,005 yang berarti hasil belajar kognitif antara kelas eksperimen dan kelas kontrol berbeda signifikan.

\section{PEMBAHASAN}

Berdasarkan hasil penelitian yang telah dilakukan pada peserta didik kelas IX di SMP Negeri 3 Natar menunjukan bahwa penerapan model pembelajaran inkuiri terbimbing berbasis kearifan lokal berpengaruh signifikan terhadap kemampuan berpikir kreatif peserta didik. Hal ini dapat dilihat dari hasil analisis pada Tabel 2 yang menunjukan bahwa kemampuan berpikir kreatif peserta didik pada kelas eksperimen lebih baik daripada kelas kontrol. Selain itu berdasarkan Tabel 3, dapat diketahui bahwa hampir seluruh indikator kemampuan berpikir kreatif pada kelas eksperimen memiliki kriteria sangat baik sedangkan kelas kontrol hanya memiliki kriteria baik. Hal ini disebabkan oleh pelaksanaan pembelajaran kelas eksperimen dengan model inkuiri terbimbing berbasis kearifan lokal yang berpusat pada peserta didik yang aktif dalam proses pembelajaran sehingga peserta didik memiliki pengalaman secara langsung dalam melakukan eksplorasi dan observasi alam sekitar secara ilmiah melalui rangkaian 
kegiatan yang sistematis dan interaksi secara aktif bersama anggota kelompoknya. Dengan melakukan tahapan-tahapan yang sistematis diawali dengan orientasi oleh pendidik, keingintahuan peserta didik terhadap kegiatan pembelajaran akan tumbuh, peserta didik dapat mengajukan pertanyaan kepada pendidik untuk selanjutnya mendapat bimbingan dari pendidik, kemudian peserta didik diberikan kesempatan untuk melakukan eksplorasi agar dapat mengumpulkan data guna menjawab rumusan masalah dan hipotesis pembelajaran. Rumusan masalah yang dipecahkan oleh peserta didik melatih kemampuan bekerjasama dalam memberikan gagasan atau ide dalam menyelesaikan permasalahan dan memberikan penafsiran terhadap suatu masalah yang peserta didik temui pada saat melakukan eksplorasi dan observasi alam sekitar. Selain itu, peserta didik juga dituntut untuk menghasilkan gagasan penyelesaian masalah yang bervariasi dan dengan sudut pandang yang berbeda. Sehingga pada akhir pembelajaran, peserta didik dapat merumuskan kesimpulan dari proses pembelajaran secara kreatif. Menurut Dyer (2009: 5) terdapat lima komponen yang dapat dilakukan untuk membangun kemampuan berpikir kreatif yaitu observing, questioning, experimenting, associating, dan networking. Kelima komponen tersebut terintegrasi dalam sintaks inkuiri terbmbing berbasis kearifan lokal yang digunakan dalam proses pembelajaran sehingga kemampuan berpikir kreatif kelas eksperimen terlatih dengan baik. Menurut Kuthlau, Leslie dan Caspary (2007: 67) melalui inkuiri terbimbing kemampuan berpikir kreatif peserta didik dapat dikembangkan. Pembelajaran inkuiri terbimbing dapat membantu peserta didik berpikir kreatif dan menemukan solusi kreatif dari suatu permasalahan.

Inkuiri terbimbing yang diintegrasikan dengan kearifan lokal dapat memberikan kesempatan kepada peserta didik untuk mengembangkan dan mengasah kemampuan berpikir kreatif yang dimiliki dalam pembelajaran khususnya mampu menyelesaikan permasalahan yang berkaitan dalam kehidupan sehari-hari. Perbedaan pencapaian kemampuan berpikir kreatif peserta didik antara kelas eksperimen dan kelas kontrol dari hasil pretest-posttest dapat diamati pada gambar berikut.

2. Tanaman transgenik

d. Hibridoma

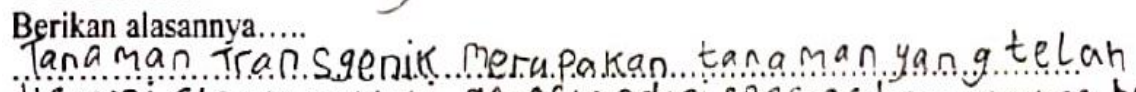

disisipi ataumemikiki genas ingdari spe.sie t tanamanyang berbeda,

Sehingapenggabungangen tertujuan unitukmendapat kan tant wan yg tahan

Tapai pisang merupakan contoh hasil bioteknologi konvensional dalam bidang ter sakdap serangan

nancan meneana Tapai pisang termasuk bioteknologi konvensional, kecuali.....

Gambar 2. Jawaban peserta didik pada salah satu soal indkator fluency kelas eksperimen

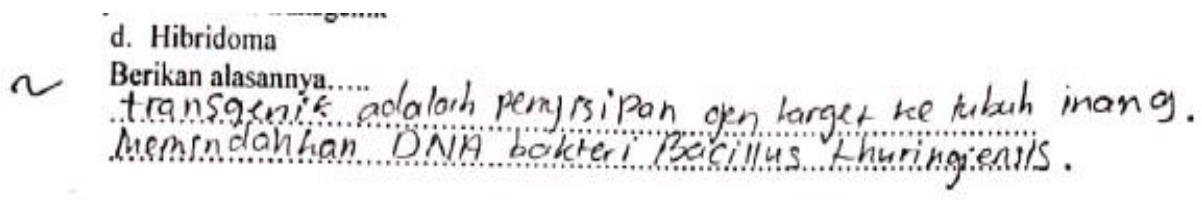

Gambar 3. Jawaban peserta didik pada salah satu indikator fluency kelas kontrol

Pada indikator ini peserta didik diminta untuk menuliskan banyak jawaban dalam menyelesaikan suatu permasalahan. Berdasarkan Gambar 5 dan 6 dapat diketahui bahwa peserta didik pada kelas eksperimen memberikan banyak jawaban dalam menyelesaikan suatu permasalahan sebagai salah satu perilaku berpikir kreatif. Selain 
itu jawaban juga lebih lengkap dan sesuai dengan deskriptor pada soal tes sehingga mendapatkan skor maksimal 3. Sedangkan peserta didik pada kelas kontrol mendapatkam skor 1 karena memberikan jawaban yang kurang lengkap dan kurang sesuai dengan deskriptor pada soal tes. Hal ini dikarenakan pada kelas eksperimen yang dibelajarkan dengan inkuiri terbimbing berbasis kearifan lokal dalam aktivitasnya di kelas melakukan kerjasama untuk menggali konsep yang mereka temukan secara inkuiri, sehingga saat berjumpa dengan suatu masalah yang berkaitan dengan lingkungan sekitar dapat berpikir lancar untuk menyelesaikan masalah tersebut secara mandiri. Penerapan model inkuiri terbimbing dapat melatih peserta didik untuk berpikir lancar (fluency), pengajuan masalah dengan mengungkapkan berbagai macam pertanyaan dari suatu informa merupakan salah satu kegiatan yang mengarah pada pengembangan berpikir kritis dan kreatif ( Siswono, 2006: 10).

Indikator flexibility kelas eksperimen lebih tinggi dibanding kelas kontrol.Pada jawaban soal pretest-posttest dari salah satu soal yang berindikator flexibility peserta didik diminta untuk memberikan penafsiran terhadap suatu masalah.

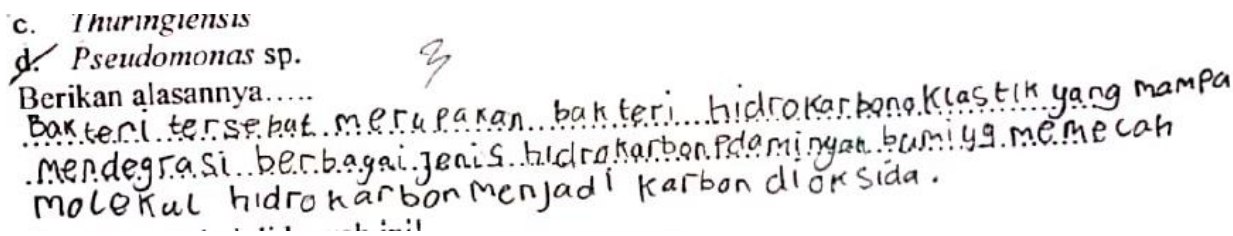

Gambar 4. Jawaban peserta didik padasalah satu soal indikator flexibility kelas eksperimen

a. Streptococcus thermophillus

b. Lactobacillus bulgaricus

c. Thuringiensis

\$. Pseudomonas sp.

Berikan alasannya.....lm pengolahon limbah minyak krna mampa las kontrol

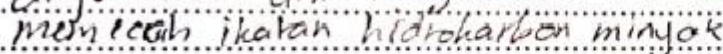

Melalui jawaban yang dituliskan oleh peserta didik kelas eksperimen, diketahui bahwa peserta didik sudah dapat memberikan penafsiran terhadap suatu masalah sesuai dengan konteks dan pemikirannya sehingga mendapatkan skor 3. Sedangkan pada kelas kontrol, peserta didik mendapatkan skor 2 karena belum bisa memberikan penafsiran terhadap suatu masalah sesuai dengan konteks dan pemikirannya namun sudah menunjukan kemampuannya untuk menjawab. Hal ini dikarenakan pada kelas kontrol, peserta didik tidak dilatih untuk mengembangkan kemampuan berpikirnya untuk menyelesaikan masalah dengan banyak cara dan hanya terpaku dengan buku sehingga tidak melakukan hal lain untuk menyelesaikan masalah tersebut. Fitri dan Septifiana (2013: 19) menyebutkan bahwa tingginya kemampuan flexibility peserta didik salah satunya dicirikan dengan kemamuan peserta didik dalam memikirkan berbagai macam cara untuk menyelesaikan suatu masalah.

Indikator originality pada kelas eksperimen juga lebih tinggi dibandingkan dengan kelas kontrol berdasarkan gambar berikut. Pada indikator ini peserta didik diminta untuk memberikan gagasan baru dalam menyelesaikan suatu masalah. 


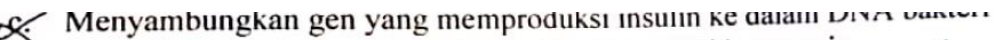

Berikan alasannya.... Bio tehnologi.dibıdang.kedokt.erar...banyakditemukan

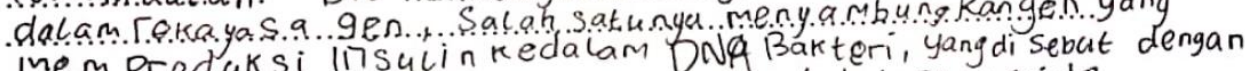

inem Produksi 17 sulin kedalam DNA Bakteri, yangdi sebat

Gambar 6. Jawaban peserta didik padasalah satu soal indikator originality kelas eksperimen

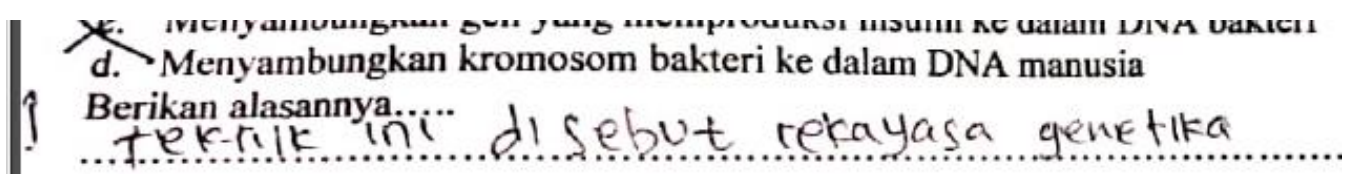

Gambar 7. Jawaban peserta didik padasalah satu soal indikator originality kelas kontrol

Jawaban peserta didik pada kelas kontrol tidak memberikan gagasan baru untuk menjawab masalah yang ada di dalam pertanyaan melainkan hanya mengulang kalimat yang ada pada soal sehingga mendapatkan skor 1. Sedangkan jawaban peserta didik pada kelas eksperimen memberikan gagasan baru dalam menyelesaikan masalah yang ada dalam pertanyaan dengan memberikan contoh teknik yang tepat sehingga mendapatkan skor 3. Menurut Munandar (2009: 48) berpikir orisinal (Originality) menyebabkan seseorang mampu melahirkan ungkapan-ungkapan baru yang unik atau mampu menemukan kombinasi-kombinasi yang tidak biasa dari unsur-unsur yang biasa.

Indikator elaboration kelas eksperimen lebih tinggi dibanding kelas kontrol. Pada indikator ini peserta didik diminta agar dapat menambahkan atau memperinci suatu gagasan, sehingga meningkatkan kualitas gagasan tersebut.

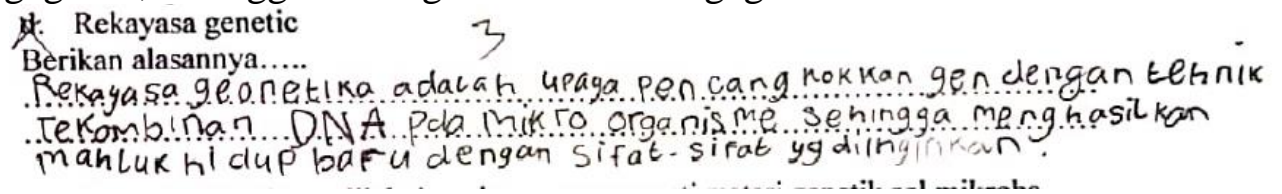

Gambar 8. Jawaban peserta didik padasalah satu soal indikator elaboration kelas eksperimen

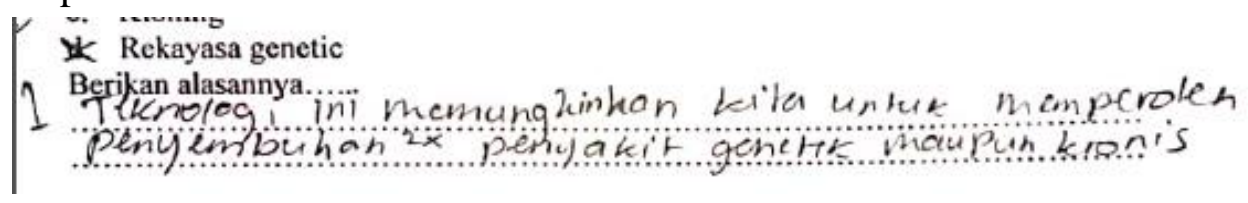

Gambar 9. Jawaban peserta didik padasalah satu soal indikator elaboration kelas kontrol

Jawaban peserta didik kelas eksperimen menambahkan suatu gagasan, sehingga meningkatkan kualitas gagasan yang terdapat pada soal sehingga mendapatkan skor maksimal 3. Sedangkan kelas kontrol tidak meningkatkan kualitas gagasan yang terdapat pada soal melainkan hanya mengulang kalimat pada soal sehingga mendapatkan skor 1. Menurut Munandar (2009: 59) berpikir memerinci (elaboration) menyebabkan seseorang mampu memperkaya dan mengembangkan suatu gagasan yang sudah ada. Melalui model pembelajaran inkuiri terbimbing berbasis kearifan lokal peserta didik dilatih kemampuan berpikir kreatifnya agar memiliki kreativitas dalam melaksanaan pembelajaran. Dalam proses pembelajaran peserta didik belajar berorientasi pada bimbingan dan petunjuk dari pendidik hingga dapat memahami konsep-konsep pembelajaran. Model pembelajaran inkuiri terbimbing yang diintegrasikan dengan kearifan lokal masyarakat setempat dapat mengkonstruksi pengetahuan yang telah mereka miliki dengan konsep baru yang ditemukan melalui 
proses inkuiri sehingga peserta didik dapat memahami konsep pembelajaran yang dimaksud melalui kearifan lokal daerah dimana mereka tinggal serta memahami bahwa sesungguhnya terdapat hubungan yang berkaitan antara pengalaman belajar peserta didik melalui proses penemuan inkuiri dengan kebudayaan setempat. Model inkuiri terbimbing berbasis kearifan lokal menjadikan peserta didik lebih aktif, kritis, kreatif dan mengemukakan sebuah data dengan hasil percobaan yang telah dilakukan dengan bimbingan guru (Lestari, 2018: 8). Dengan demikian melalui model inkuiri terbimbing berbasis kearifan lokal kemampuan berpikir kreatif yang dimiliki peserta didik dapat berkembang.

\section{SIMPULAN}

Berdasarkan hasil penelitian dan pembahasan, maka dapat disimpulkan bahwa ada pengaruh yang signifikan dalam penerapan model pembelajaran inkuiri terbimbing berbasis kearifan lokal terhadap kemampuan berpikir kreatif peserta didik pada materi bioteknologi kelas IX di SMP Negeri 3 Natar.

\section{DAFTAR RUJUKAN}

Awang dan Ramly. 2008. Creative Thingking Skill Approach Through Problem Based Learning: Pedagogy and Practice in the Engineering Classroom. International Journal of Human And Social Science. Vol 3. No 1.

Azizahwati, dkk. 2015. Pengembangan Modul Pembelajaran Fisika SMA Berbasis Kearifan Lokal untuk Meningkatkan Hasil Belajar Siswa. Prosiding Pertemuan Ilmiah XXIX HFI Jateng \& DIY. Vol. 2. No 10.

Dharma. 2008. Kreativitas. Direktorat Jenderal Peningkatan Mutu Pendidik dan Tenaga Kependidikan Departemen Pendidikan Nasional. Jakarta.

Dyer, J., Dkk. 2009. Innovators DNA: Mastering The Five Skills Of Disruptive Innovators. Harvard Business Review Press. Boston. Vol 6. No 2.

Fitri, S. G., dan Septifiana, V. 2013. Kreativitas Siswa Dalam Pembuatan Model Struktur 3D Sel Pada Pembelajaran Subkonsep Struktur Dan Fungsi Sel. Seminar Dan Rapat Tahunan Bidang Ilmu MIPA BKS PTN Barat. FMIPA UNILA. Bandar Lampung

Florida, R., Mellander, C., dan King, K. 2015. The Global Creativity Index 2015. Martin Prosirety Institute. Canada.

Hendra. 2007. Strategi Jitu Mencapai Kesuksesan Belajar. PT. Elex Media Komputindo. Jakarta

Kemendikbud. 2013. Permendikbud No. 81A Tahun 2013 tentang Ilmu Pengetahuan Alam (IPA). Kemendikbud. Jakarta.

Kuthlau, C. C., Leslie, M. K dan Caspary, A. K. 2007. Guided Inquiry: Learning in The $21^{\text {st }}$ Century. Liberaries Unlimited. London.

Lestari, Asih. 2018. Identifikasi Kearifan Lokal Di Sungai Way Kiri Kabupaten Tulang Bawang Barat Sebagai Sumber Belajar Ipa SMP (Skripsi). Universitas Lampung. Lampung.

Munandar, U. 2009. Pengembangan Kreativitas Anak Berbakat. PT. Rineka Cipta. Jakarta.

Rustaman, N. 2005. Strategi Belajar Mengajar Biologi. UM Press. Malang.

Sardjiyo dan Panen, P.2005. Pembelajaran Berbasis Budaya: Model Inovasi Pembelajaran Dan Implementasi Kurikulum Berbasis Kompetensi. Jurnal Pendidikan. Vol 6. No 2. 
Siswono, T. Y. E. 2011. Level Of Student's Creative Thinking In Classroom Mathematics. Journal Educational Research And Review. Vol 6. No 7.

Siswono, T. Y. 2006. Upaya Meningkatkan Kemampuan Berpikir Kreatif Siswa Melalui Pengajuan Masalah. Jurnal Matematika dan Sains. Vol 10 No 1.

Suardana, Momon. 2013. Mengembangkan Keterampilan Berpikir Kreatif. Rajawali Pres. Jakarta

Tilaar, H.A.R. 2010. Paradigma Baru Pendidikan Nasional. Rineka Cipta. Jakarta.

Wijayanti, dkk. 2014. Meningkatkan Minat dan Prestasi Belajar Matematika Dengan Model Pembelajaran Grup Investigation. Jurnal Pendidikan Matematika UNION. Vol 2 No 1. 